\title{
Studies on interaction between CdTe quantum dots and $\alpha$-chymotrypsin by molecular spectroscopy
}

\author{
JIANNIAO TIAN ${ }^{1}$, SHENGZHI WEI $^{1}$, YANCHUN ZHAO ${ }^{1}$, RONGJUN LIU ${ }^{1}$ and \\ SHULIN ZHAO ${ }^{2}$ \\ ${ }^{1}$ Key Laboratory for the Chemistry and Molecular Engineering of Medicinal Resources \\ (Guangxi Normal University), Ministry of Education of China, Guilin, 541004, China \\ ${ }^{2}$ College of Chemistry and Chemical Engineering of Guangxi Normal University, Guilin, 541004, China \\ e-mail: tianjn58@yahoo.com.cn
}

MS received 4 May 2009; revised 2 July 2009; accepted 5 August 2009

\begin{abstract}
In this article, the interaction between $\alpha$-Chymotrypsin and CdTe QDs was investigated by fluorescence, synchronous fluorescence, and circular dichroism (CD) spectroscopic methods at $\mathrm{pH} 7 \cdot 20$ and $\mathrm{pH} 9 \cdot 05$. The intrinsic fluorescence of $\alpha$-Chy is quenched by $\mathrm{CdTe}$ QDs. Under different $\mathrm{pH}$ conditions, the level of binding constants is determined to be $10^{3}$ from fluorescence data. The hydrogen bond or van der Waals force is involved in the binding process when $\mathrm{pH}$ is 9.05 , while the hydrophobic and electrostatic interactions play main role in the binding process when $\mathrm{pH}$ is $7 \cdot 20$. The red-shift of synchronous fluorescence spectral peak of protein after the addition of CdTe QDs reveals that the microenvironments around tryptophan residues are disturbed by CdTe QDs. The secondary structure of $\alpha$-Chy undergoes slight changes as similar by far-UV CD data. The activity and stability of $\alpha$-Chy in the presence of CdTe QDs were also studied. $\alpha$-Chy can maintain its high activity and stability under different $\mathrm{pH}$ conditions for $24 \mathrm{~h}$ in the presence of CdTe QDs.
\end{abstract}

Keywords. CdTe QDs; $\alpha$-chymotrypsin; interaction; fluorescence spectroscopy; CD spectroscopy; enzyme activity.

\section{Introduction}

Luminescent semiconductor quantum dots (QDs), also called nanocrystals (NCs), have attracted increasing attention in the past decade. ${ }^{1}$ Because of quantum confinement, the QDs possess unique optical properties, such as tunable PL, high photostability, long luminescence lifetime and attractive spectrum with narrow emission and broad excitation. ${ }^{1}$ Because of these properties, the use of QDs has been demonstrated in biology and medicine as fluorescent probes and more recently in analytical chemistry. ${ }^{2-7}$ Colloidal semiconductor CdTe QDs, in particular, are of interest due to their large Bohr radius $(7.3 \mathrm{~nm})$ and the relatively small band gap $(1.475 \mathrm{eV})$, leading to a pronounced quantum size effect in a range of CdTe QDs with a diameter up to $10 \mathrm{~nm}$. In addition, the absorption and emission spectra of these QDs can reach the near-IR spectral regime. CdTe QDs are nanoscale spherical particles

*For correspondence that have the potential to overcome some of the functional limitations encountered by organic dyes in fluorescence labelling applications. ${ }^{8}$ Recently, mesoporous sllica beads or polystyrene beads doped with multicolour QDs have been used for biological applications, including DNA detection, multiplexed bioassays, and immunoassays of immunoglobulin $\mathrm{G}$ (IgG); however, the studies have been rather limited. ${ }^{9-10}$

It is well known that enzymes are mild, highly specific and efficient biocatalysts in a wide range of applications. ${ }^{11-13} \alpha$-Chymotrypsin ( $\alpha$-Chy) is one of the most studied enzymes and its structure and mechanism of action are well-known. ${ }^{14}$ The $\alpha$-Chy is a globular $\beta$ protein with 245 amino acids and a secondary structure dominant in anti-parallel $\beta$-sheet with a small $\alpha$-helix content that has a catalytic activity in the hydrolysis of ingested proteins in the intestine. ${ }^{15}$ The activity of the enzyme is modified by the presence of lipid/water interfaces and extensive studies have been reported regarding the characteristics of esters (such as 2-naphthylacetate) and 
amides ( $N$-glutaryl-l-phenylalanine $p$-nitroanilide) hydrolysis in reverse micellar solutions ${ }^{16}$ and aqueous surfactant solutions. ${ }^{17}$ It is well-known that $\alpha$ Chy, and as other proteases such as, protein kinases and phosphatases, possesses a broad selectivity toward their substrates; $\alpha$-Chy substrates can be divided into 'poor' and 'good' substrate, depending on their kinetic parameters, especially $\mathrm{kcat} / \mathrm{K}_{\mathrm{M}}$; this 'specificity constant' has been properly used to obtain information about enzyme-substrate specificity. ${ }^{18}$

In this study, the applicability of the CdTe QDs modified by thioglycolic acid to the labelling of $\alpha$ chymotrypsin ( $\alpha$-Chy) was investigated by a spectroscopic method. Fluorescence spectroscopy was employed to understand the quenching mechanism of CdTe-Chy. Effects of CdTe QDs on conformational changes of $\alpha$-Chy were investigated by synchronous fluorescence spectroscopy and circular dichroism (CD). The binding constants have been determined and the binding mode inferred from the thermodynamic parameters.

\section{Experimental}

\subsection{Materials}

A standard solution of $\alpha$-Chy containing $2 \mathrm{mg} / \mathrm{ml}$ $\left(8 \times 10^{-5} \mathrm{M}\right)$ was prepared. $N$-acetyl-L-tyrosine ethyl ester (ATEE) and $\alpha$-Chy were obtained from Chinese Drug and Biological Product Detection Institute. All other chemicals used were analytical grade reagents. Doubly distilled water was used for the preparation of all solutions.

\subsection{Preparation of NaHTe}

NaHTe solution was prepared according to the reported method with minor modifications. ${ }^{19}$ Deoxygenized water $(4 \mathrm{ml})$ was added to $\mathrm{NaBH}_{4}$ $(0.275 \mathrm{~g})$ held in a small flask. After the solution was cooled with ice-water, tellurium powder $(0.220 \mathrm{~g})$ was added with continuous stirring. The stirring was continued for $8 \mathrm{~h}$ until all of the tellurium powder was dissolved. The final solution was used for further experiments.

\subsection{Preparation of CdTe QDs}

CdTe QDs were prepared using the reported method with minor modifications. ${ }^{20} \mathrm{CdCl}_{2} \cdot 2 \cdot 5 \mathrm{H}_{2} \mathrm{O}(0 \cdot 2854 \mathrm{~g})$ was dissolved in $280 \mathrm{ml}$ of water, thioglycolic acid $(0.22 \mathrm{ml})$, was added under stirring and the $\mathrm{pH}$ was adjusted to 11.20 by drop-wise addition of $0.1 \mathrm{M}$ solution of $\mathrm{NaOH}$. The solution was placed in a three-necked flask fitted with a septum, deaerated by bubbling $\mathrm{N}_{2}$ for about $30 \mathrm{~min}$. Under stirring, $1.50 \mathrm{ml}$ of freshly prepared oxygen-free NaHTe solution was added to the solution rapidly. The resulting mixture was heated under reflux at $100^{\circ} \mathrm{C}$ for $3 \mathrm{~h}$. The final concentration of QDs was $4.5 \times$ $10^{-3} \mathrm{M}$ (referring to as $\mathrm{Cd}^{2+}$ here in after) and was stored at $4^{\circ} \mathrm{C}$.

\subsection{Apparatus and methods}

Transmission electron micrographs (TEM) of CdTe QDs were performed on JEM-2100F $(200 \mathrm{kV})$. In spectroscopic experiments, the $\alpha$-Chy solution was introduced into the CdTe QDs colloid at a certain concentration. The incubation time was about $2.5 \mathrm{~h}$ in order to attain binding equilibrium. Fluorescence spectra were measured with a LS-55 (Perkin-Elmer, USA) spectrofluorimeter equipped with a xenon lamp, $1 \mathrm{~cm}$ quartz cell, using $8 \mathrm{~nm} / 8 \mathrm{~nm}$ slit widths. The excitation wavelength was $280 \mathrm{~nm}$, and the emission was recorded at $290-450 \mathrm{~nm} .0 \cdot 1 \mathrm{ml}$ of the $8.0 \times 10^{-5} \mathrm{M} \alpha$-Chy solution and an appropriate volume of the CdTe QDs colloid solution were placed into a $5 \mathrm{ml}$ volumetric flask. The mixture was diluted to $5 \mathrm{ml}$ with physiological buffer. All experiments were measured at four temperatures (278, 290,298 and $308 \mathrm{~K}$ ). The data were analysed by using the Stern-Volmer equation to calculate the binding constants.

The synchronous fluorescence spectra were recorded by scanning simultaneously the excitation and emission wavelength at 15 or $60 \mathrm{~nm}$ intervals.

Circular dichroism (CD) measurements were carried out on a Jasco J-810 sepectrophotometer using a $1 \mathrm{~cm}$ quartz cell. The CD spectra of $\alpha$-Chy solutions containing CdTe QDs were recorded from 190 to $300 \mathrm{~nm}$. Corresponding absorbance contributions to CdTe QDs colloid and buffer were also measured and were subtracted from those for the test solutions.

For the measurement of $\alpha$-Chy activity, $N$-acetylL-tyrosine ethyl ester (ATEE) was used; the change in absorbance at $237 \mathrm{~nm}$ was followed in the reaction mixture $(2.8 \mathrm{ml})$ containing $5 \mathrm{mM}$ physiological buffer ( $\mathrm{pH} 7.20$ or $\mathrm{pH} 9.05)$ and $1 \mathrm{mM}$ ATEE. The reactions were initiated by adding $0.2 \mathrm{ml}$ of $2 \mathrm{mg} / \mathrm{ml}$ enzyme. $^{21}$ 


\section{Results and discussion}

\subsection{Fluorescence studies of $\alpha$-Chy quenched by CdTe QDs}

Figure 1 shows transmission electron microscopy (TEM) images of the CdTe QDs. The morphology and size of CdTe QDs could be observed clearly. The particles appear spherical and no aggregation was observed. The average size of studied $\mathrm{CdTe}$ QDs was about 3-4 $\mathrm{nm}$, and considered close to the value resulting from the empirical formula which seems to be convenient to calculate the size of CdTe QDs. ${ }^{22}$

The interaction of CdTe with $\alpha$-Chy at different $\mathrm{pH}$ conditions was evaluated by monitoring the intrinsic fluorescence intensity changes of $\alpha$-Chy upon addition of CdTe. Fluorescence quenching spectra of $\alpha$-Chy at the presence of various concentrations of CdTe are shown in figure 2. Fluorescence of $\alpha$-Chy originates from tryptophan (Trp), tyrosine (Tyr) and phenylalanine (Phe) residues. Actually, $\alpha$ Chy has eight tryptophan (Trp) residues. The intrinsic fluorescence of $\alpha$-Chy is mainly contributed by the Trp residue alone, because the Phe residue has a very low quantum yield and the fluorescence of Tyr is almost totally quenched when it is ionized or when it is near an amino group, a carboxyl group or a Trp. ${ }^{23}$ The change of intrinsic fluorescence inten-

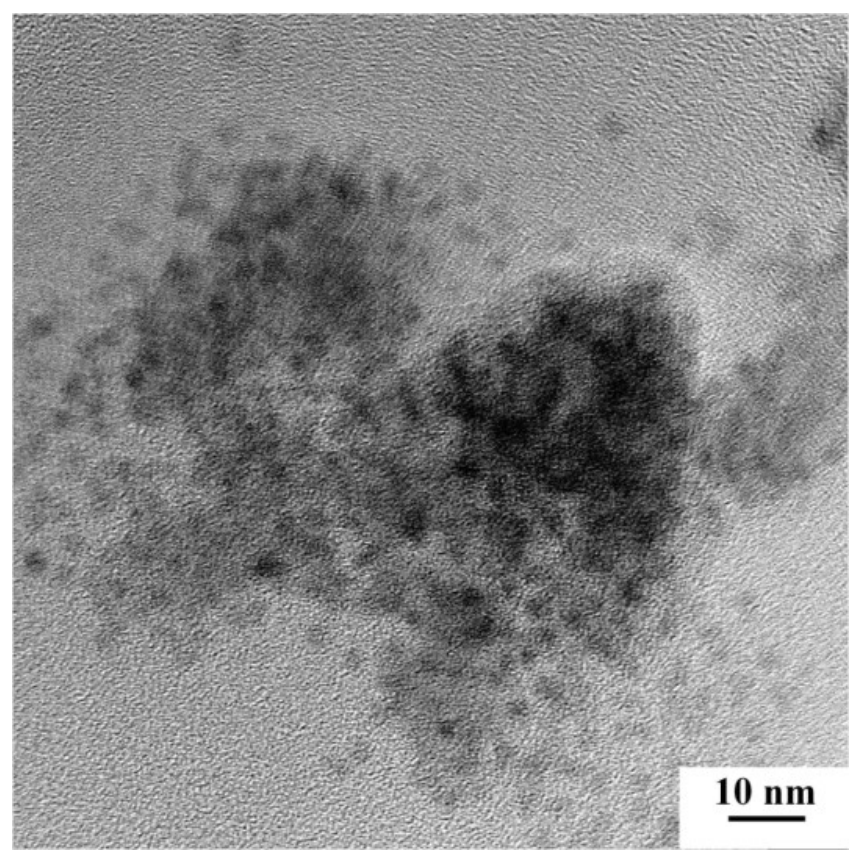

Figure 1. The TEM graph of CdTe QDs. sity of $\alpha$-Chy is mainly generated by $\operatorname{Trp}$ residue when small molecule substances are bound to $\alpha$ Chy. As illustrated in figure 2, the fluorescence spectra of enzyme upon excitation at $280 \mathrm{~nm}$ at $\mathrm{pH}$ 7.20 and 9.05 show an identical emission maximum at $350 \mathrm{~nm}$, which is characteristic of partial shielding of the tryptophan residues from aqueous solvent. $^{24}$

The addition of CdTe QDs resulted in a distinct red shift in the wavelength maximum and a corresponding decrease in the fluorescence intensity, implying that the binding of CdTe QDs to $\alpha$-Chy occurs and the microenvironment around chromospheres of $\alpha$-Chy is changed. Furthermore, the change of $\alpha$-Chy fluorescence at two $\mathrm{pH}$ values is
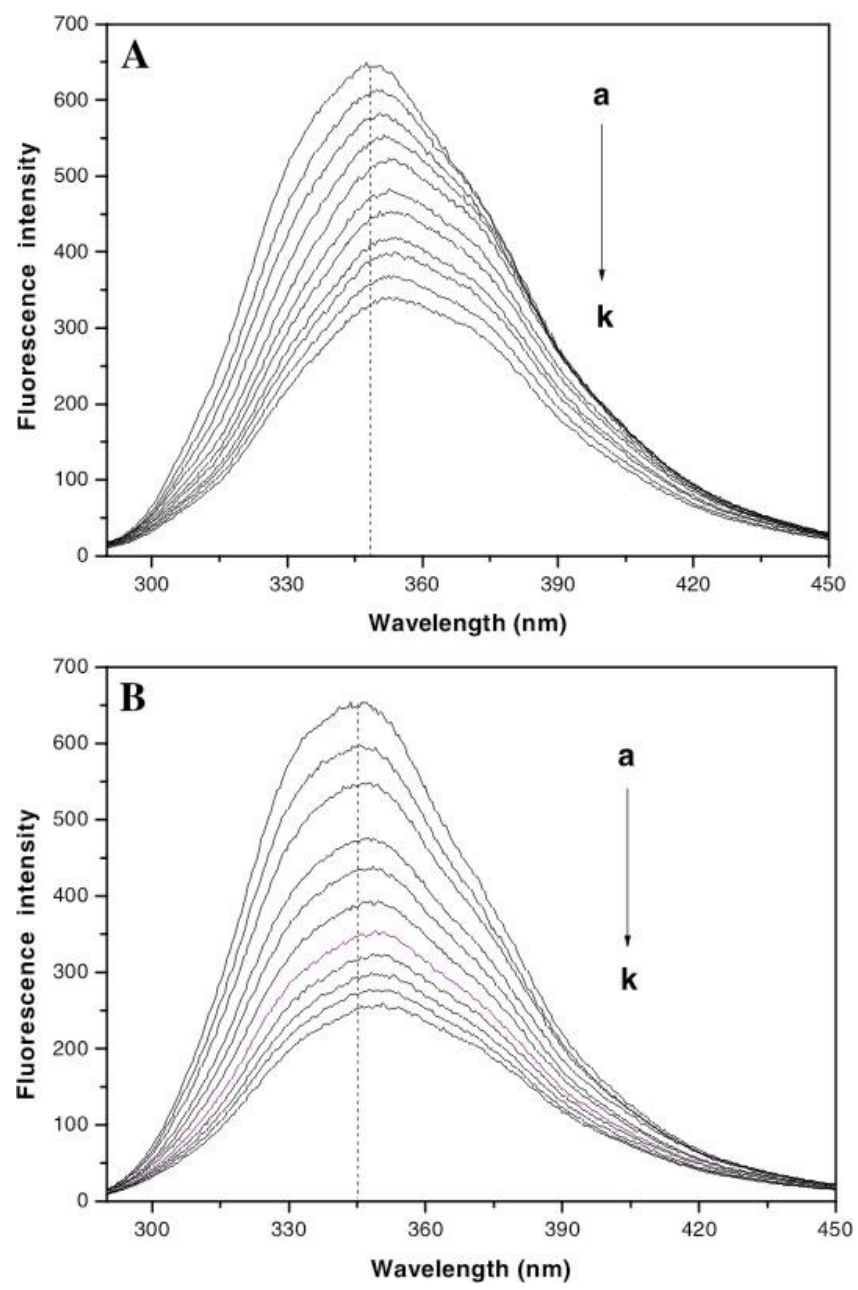

Figure 2. Fluorescence spectra of $\alpha$-Chy in the absence and presence of CdTe QDs. The concentration of $\alpha$-Chy was fixed as $1.6 \times 10^{-6} \mathrm{M}$; the concentrations of CdTe QDs from (a) to (k) were $0,0 \cdot 6,1 \cdot 20,1 \cdot 80,2 \cdot 40,3 \cdot 00$, $3 \cdot 60,4 \cdot 20,4 \cdot 80,5 \cdot 40 \times 10^{-5}$ and $6 \cdot 00 \times 10^{-5} \mathrm{M}$, respectively; (A) $\mathrm{pH}=9 \cdot 05$, (B) $\mathrm{pH}=7 \cdot 20$. 
different. At $\mathrm{pH} 9 \cdot 05$, under similar concentration of QDs, the emission maximum exhibits larger red shift and smaller decrease in the fluorescence intensity. This result indicates that the Try residues of $\alpha$ Chy under these conditions is more exposed in the polar environment. The observed fluorescence quenching probably arises from the energy transfer occurring between $\alpha$-Chy and CdTe QD, which will be proved in following results.

Fluorescence intensity data were then analysed according to Stern-Volmer quenching equation. ${ }^{25}$

$$
\frac{F_{0}}{F}=1+k_{q} \tau_{0}[Q]=1+K_{S V}[Q]
$$

Where $F_{0}$ and $F$ are the steady state fluorescence intensities of $\alpha$-Chy at $348 \mathrm{~nm}$ before and after the addition of quencher (CdTe), Ksv and $[Q]$ are the Stern-Volmer dynamic quenching constant and the concentration of quencher CdTe, respectively, $\mathrm{kq}$ is the quenching rate constant of biomolecule, $\tau_{0}$ is the average life-time of bimolecular without the quencher and its value is $5 \mathrm{~ns} .^{26}$ The solid lines in figure 3 show the lines of best fit of the experimental data to the Stern-Volmer equation. The values for $K_{\mathrm{Sv}}, k_{\mathrm{q}}, R$, and linear regression equation at different temperatures are presented in table 1. The results in table 1 show $K_{\mathrm{SV}}$ is inversely correlated with temperature, which suggests that the fluorescence quenching process may be mainly controlled by a static quenching mechanism rather than a dynamic quenching mechanism. Moreover, values for $k_{q}$ (table 1) are two orders of magnitude greater than the maximum diffusion collision quenching rate constant $\left(2.0 \times 10^{10} \mathrm{~L} / \mathrm{mol} / \mathrm{s}\right)$ of a variety of quenchers with biopolymer. ${ }^{27}$ This result indicates again that the quenching is not caused by dynamic collision but from the formation of a complex.

For the static quenching process, the quenching data were analysed according to the modified SternVolmer equation. ${ }^{28}$

$$
\frac{F_{0}}{\Delta F}=\frac{1}{f_{a}}+\frac{1}{f_{a} K_{A}[Q]}
$$

In the present case, $F_{0}$ and $\Delta F$ are the relative fluorescence intensity without quencher and the difference in fluorescence intensity of protein in the absence and presence of quencher, respectively. $K_{\mathrm{A}}$ is the effective quenching constant for the accessible fluorophores, here it is binding constant and $[Q]$ is the quencher concentration; $f_{a}$ is the fractional maximum fluorescence intensity of protein summed up, and the plot of $F_{0} / \Delta F$ vs $[Q]^{-1}$ is linear with slope equaling to the value of $\left(f_{a} K_{A}\right)^{-1}$. The value $1 / f_{a}$ is fixed on the ordinate. The association constant $K_{a}$ is a quotient of an ordinate $1 / f_{a}$ and slope $\left(f_{a} K_{A}\right)^{-1}$.

Figure 4 shows the modified Stern-Volmer plots for the system of CdTe-Chy at different temperatures. The corresponding results at different temperatures are listed in table 2 .
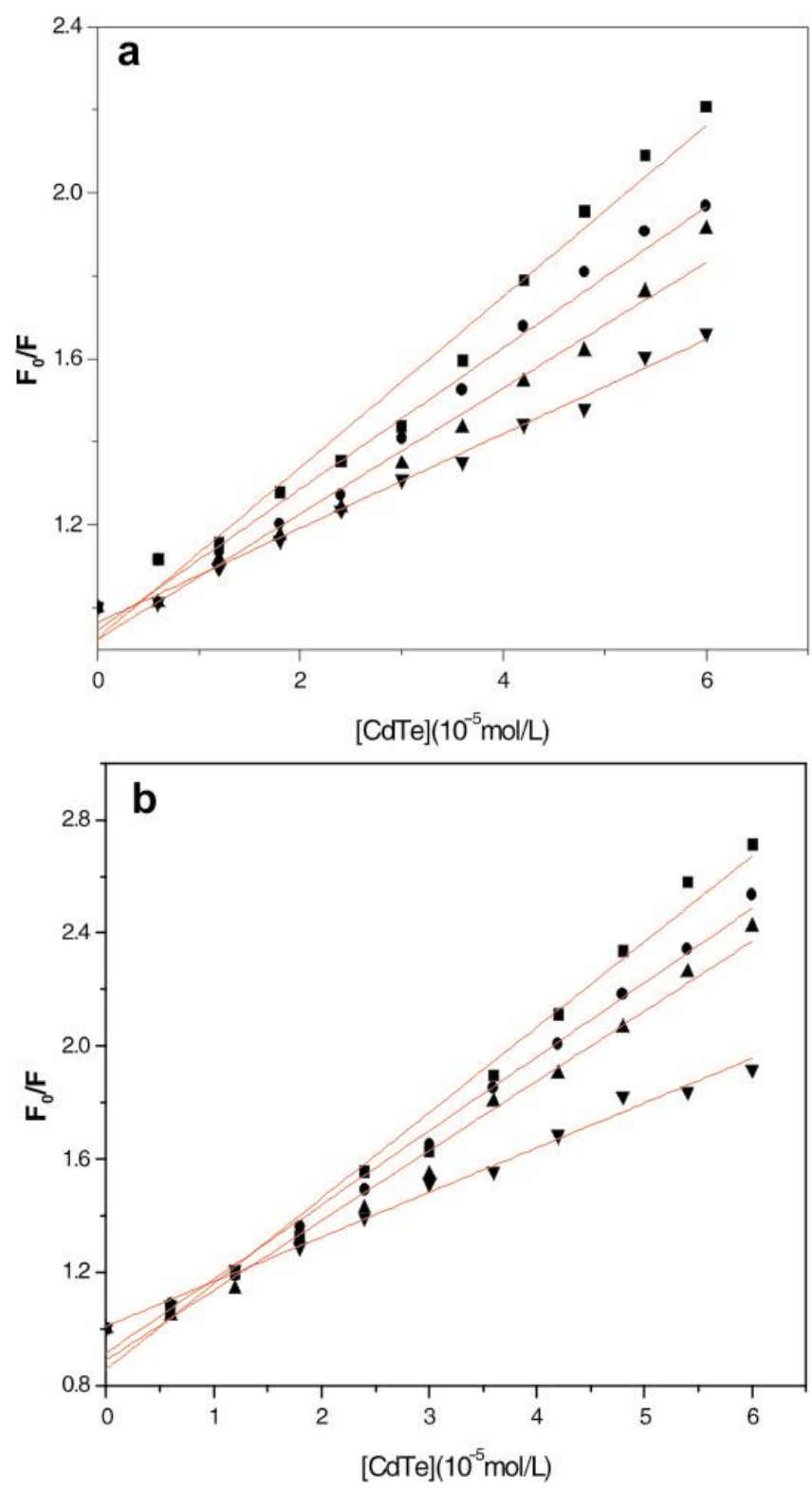

Figure 3. The Stern-Volmer plots of $\alpha$-Chy-CdTe QDs system. - $278 \mathrm{~K} ; \bullet 290 \mathrm{~K} ; \boldsymbol{\Delta} 298 \mathrm{~K} ; \boldsymbol{\nabla} 308 \mathrm{~K}$. [ $\alpha$ Chy $]=1.6 \times 10^{-6} \mathrm{M}, \lambda \mathrm{ex}=280 \mathrm{~nm} ;$ (a) $\mathrm{pH}=9.05$, (b) $\mathrm{pH}=7 \cdot 20$. 
Table 1. Stern-Volmer quenching constants of $\mathrm{CdTe}-\alpha$-Chy system at different temperatures.

\begin{tabular}{lcccc}
\hline $\mathrm{pH}$ & $\mathrm{T}(\mathrm{K})$ & $K_{\mathrm{sv}}\left(\times 10^{4} \mathrm{~L} / \mathrm{mol}\right)$ & $K_{\mathrm{q}}\left(\times 10^{12} \mathrm{~L} / \mathrm{mol} / \mathrm{s}\right)$ & $R$ \\
\hline $9 \cdot 05$ & 278 & $2 \cdot 14$ & $4 \cdot 28$ & 0.9892 \\
& 290 & $1 \cdot 76$ & $3 \cdot 52$ & 0.9889 \\
& 298 & $1 \cdot 60$ & $3 \cdot 20$ & 0.9933 \\
& 308 & 0.73 & $1 \cdot 46$ & 0.9913 \\
$7 \cdot 20$ & 278 & $3 \cdot 19$ & $6 \cdot 38$ & 0.9952 \\
& 290 & $2 \cdot 72$ & 5.44 & 0.9986 \\
& 298 & $2 \cdot 59$ & $5 \cdot 18$ & 0.9968 \\
& 308 & 1.57 & $3 \cdot 14$ & 0.9952 \\
\hline
\end{tabular}

Table 2. Binding constants $(K)$ and thermodynamic parameters for $\alpha$-Chy binding to CdTe.

\begin{tabular}{lccccc}
\hline $\mathrm{pH}$ & Temperature $(\mathrm{K})$ & $K_{\mathrm{A}}\left(10^{3} \mathrm{~L} \mathrm{~mol}^{-1}\right)$ & $\Delta G^{0}\left(\mathrm{~kJ} \mathrm{~mol}^{-1}\right)$ & $\Delta H^{0}\left(\mathrm{~kJ} \mathrm{~mol}^{-1}\right)$ & $\Delta S^{0}\left(\mathrm{~J} \mathrm{~mol}^{-1} \mathrm{~K}^{-1}\right)$ \\
\hline 9.05 & 278 & 4.65 & -19.54 & -39.04 & $-70 \cdot 13$ \\
& 290 & 2.50 & -18.70 & & \\
& 298 & 1.48 & $-18 \cdot 14$ & & \\
$7 \cdot 20$ & 308 & 1.09 & -17.44 & & \\
& 278 & 7.09 & -20.49 & 8.71 & \\
& 290 & 8.15 & -21.71 & & \\
& 298 & 8.97 & -22.55 & & \\
& 308 & 10.25 & -23.15 & & \\
\hline
\end{tabular}

Table 2 shows that the order of magnitude of $K$ is $10^{3}$. Luminescent titration experiments have shown that straight, A-tract, and 'kinky' DNA binding to CdS nanoparticles has the binding constants of $4 \times 10^{2}, 5 \times 10^{2}$ and $3 \times 10^{3} \mathrm{M}^{-1}$, respectively. ${ }^{29}$ In contrast, in the present study, the binding constants of $\alpha$-Chy to CdTe QDs are higher than those of DNA molecules. Such a high value of K explains the strong affinity of CdTe QDs surface to $\alpha$-Chy. At the same time, it can be seen that the binding of CdTe to $\alpha$-Chy at $\mathrm{pH} 7.20$ is stronger than that at $\mathrm{pH}$ 9.05 (table 2).

\subsection{Thermodynamic parameters and binding mode}

The thermodynamic parameters were analysed in order to characterize further the binding mode of $\alpha$ Chy to CdTe QDs. Basically, four types of interactions play vital roles in protein binding. These are hydrogen bonds, van der Waals forces, electrostatic forces, and hydrophobic interactions. Thermodynamic parameters, free energy changes $\left(\Delta G^{0}\right)$ enthalpy changes $\left(\Delta H^{0}\right)$ and entropy changes $\left(\Delta S^{0}\right)$ of the interactions are essential to interpret the binding mode.

Values of $\Delta G^{0}, \Delta H^{0}$, and $\Delta S^{0}$ calculated from Vant Hoff plot of $\ln K$ versus $1 / T$ (see figure 5 ) are listed in table 2. Negative values of $\Delta G^{0}$ reveal that the binding process is spontaneous under two $\mathrm{pH}$ values. When $\mathrm{pH}$ values are 7.20, a positive value of $\Delta S^{0}$ along with a lesser $\Delta H^{0}$ value is characteristic of electrostatic interactions in aqueous solution. ${ }^{30}$ Moreover, positive values of $\Delta S^{0}$ provide evidence of hydrophobic interactions. Thus, it is more likely that hydrophobic and electrostatic interactions are involved in binding of $\alpha$-Chy and QDs under $\mathrm{pH}$ $7 \cdot 20$. When the $\mathrm{pH}$ value is 9.05 , a negative value of $\Delta S^{0}$ along with a negative $\Delta H^{0}$ value is characteristic of hydrogen bonds or van der Waals forces in aqueous solution. ${ }^{30}$ The isoelectric point (pI) of $\alpha$-Chy is in the $\mathrm{pH}$ range of 8·10-8.40. Therefore, an electrostatic interaction contributes to the binding of $\alpha$-Chy to the thioglycolic acid-rich surface of CdTe QDs at $\mathrm{pH}$ 7.20. Hydrogen bonds or van der Waals forces play a main role in the binding of $\alpha$-Chy to surface of CdTe QDs at pH 9.05. Furthermore, any conformational changes of the protein invariably result in 
entropic gain under two $\mathrm{pH}$ values, ${ }^{31}$ which may be one of the important driving forces for $\alpha$-Chy binding to the surface of CdTe QDs.

\subsection{Energy transfer between $\alpha$-Chy and CdTe QDs}

According to the Förster's theory, ${ }^{32}$ the energy transfer effect is not only related to the distance between the donor (tryptophan residue) and acceptor (CdTe QDs), but also influenced by the critical
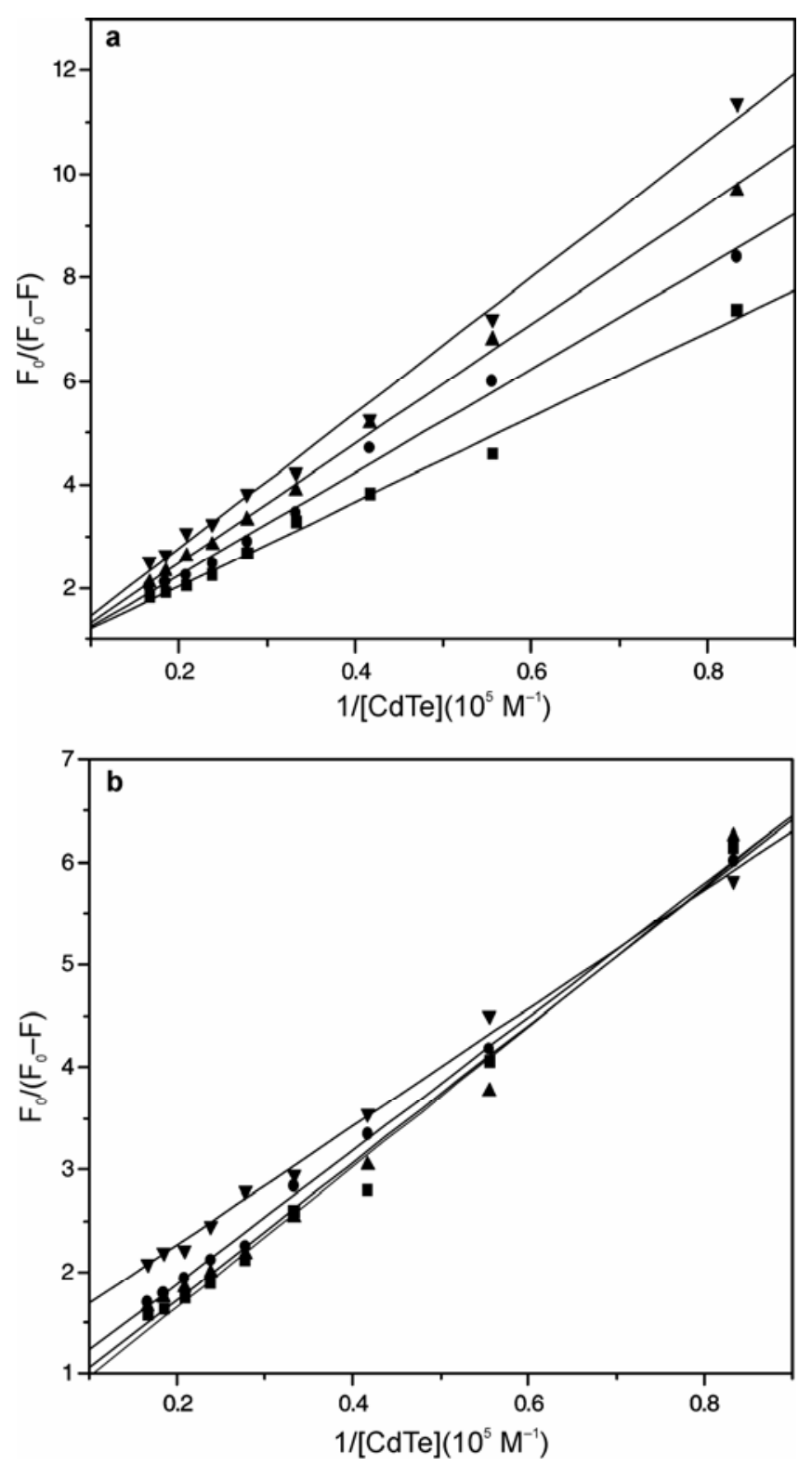

Figure 4. The modified Stern-Volmer plots for the CdTe-Chy system. $-278 \mathrm{~K} ; \quad$ - $290 \mathrm{~K} ; \boldsymbol{\Delta} 298 \mathrm{~K} ; \boldsymbol{\nabla}$ $308 \mathrm{~K}$. $[\alpha$-Chy $]=1.6 \times 10^{-6} \mathrm{M}, \lambda \mathrm{ex}=280 \mathrm{~nm} ;$ (a) $\mathrm{pH}=$ 9.05, (b) $\mathrm{pH}=7 \cdot 20$. energy transfer distance $R_{0}$. By Förster's theory, the efficiency of energy transfer $(E)$ is calculated using the equation:

$$
E=\frac{R_{0}^{6}}{R_{0}^{6}+r^{6}}
$$

where $r$ is the distance between the acceptor (CdTe) and the donor ( $\alpha$-Chy), and $R_{0}$ is the critical energy transfer distance, at which $50 \%$ of the excitation energy is transferred to the acceptor is defined by the following equation:
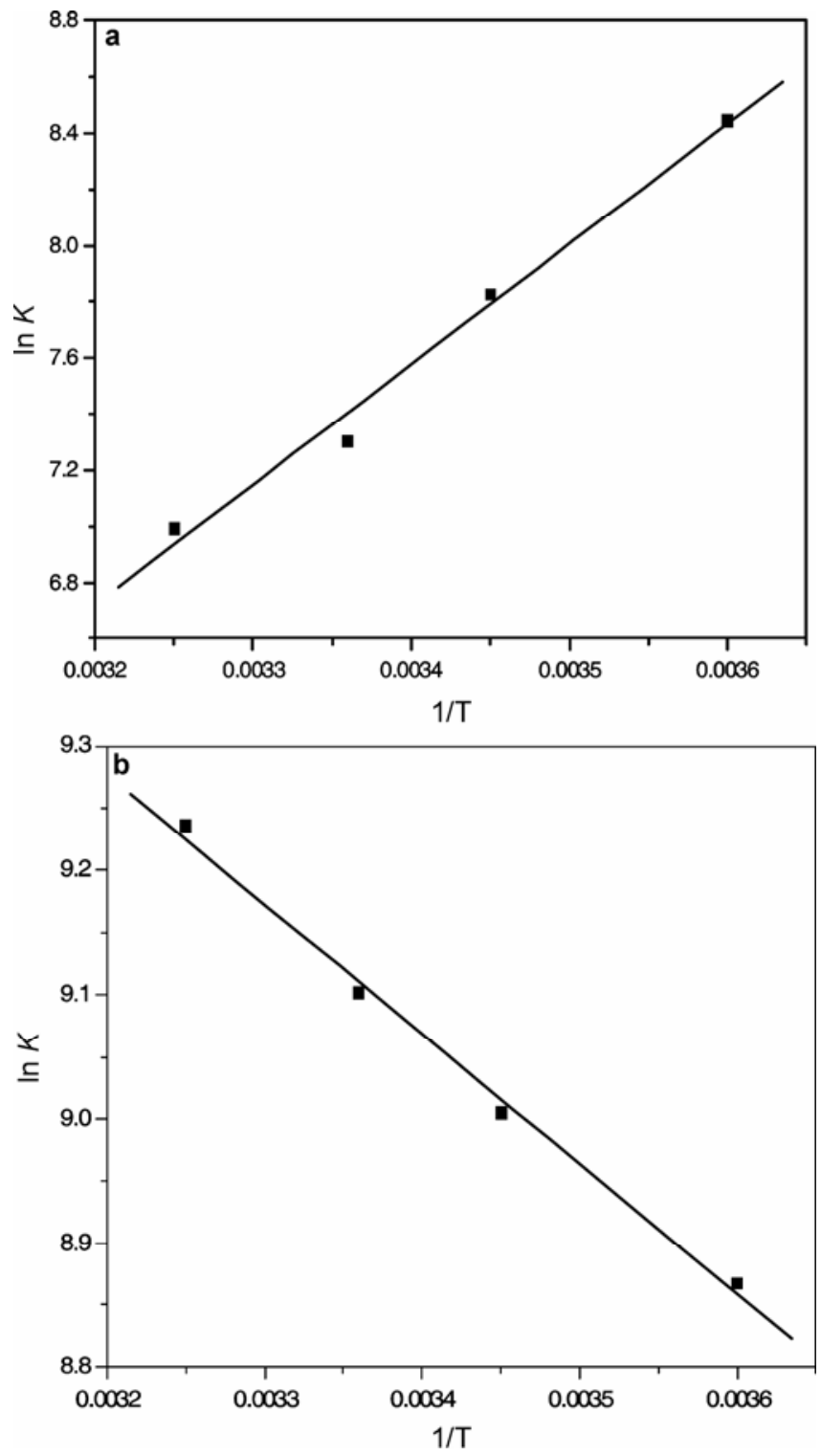

Figure 5. Vant Hoff plot, $[\alpha-\mathrm{Chy}]=1.6 \times 10^{-6} \mathrm{M}$; (a) $\mathrm{pH}=9 \cdot 05,(\mathbf{b}) \mathrm{pH}=7 \cdot 20$. 


$$
R_{0}^{6}=8 \cdot 8 \times 10^{-25} k^{2} N^{-4} \Phi J
$$

In eq. (6), $k^{2}$ is the spatial orientation factor of the dipole, $\mathrm{N}$ is the refractive index of medium, $\Phi$ is the fluorescence quantum yield of donor, and $J$ is the spectral overlap between the emission spectrum of donor and the absorption spectrum of acceptor (figure 6), which is given by:

$$
J=\frac{\sum F(\lambda) \varepsilon(\lambda) \lambda^{4} \Delta \lambda}{\sum F(\lambda) \Delta \lambda} .
$$

where $F(\lambda)$ is the fluorescence intensity of fluorescence donor at wavelength of and $\varepsilon(\lambda)$ is molar absorbance coefficient of the acceptor when wavelength is $\lambda$.
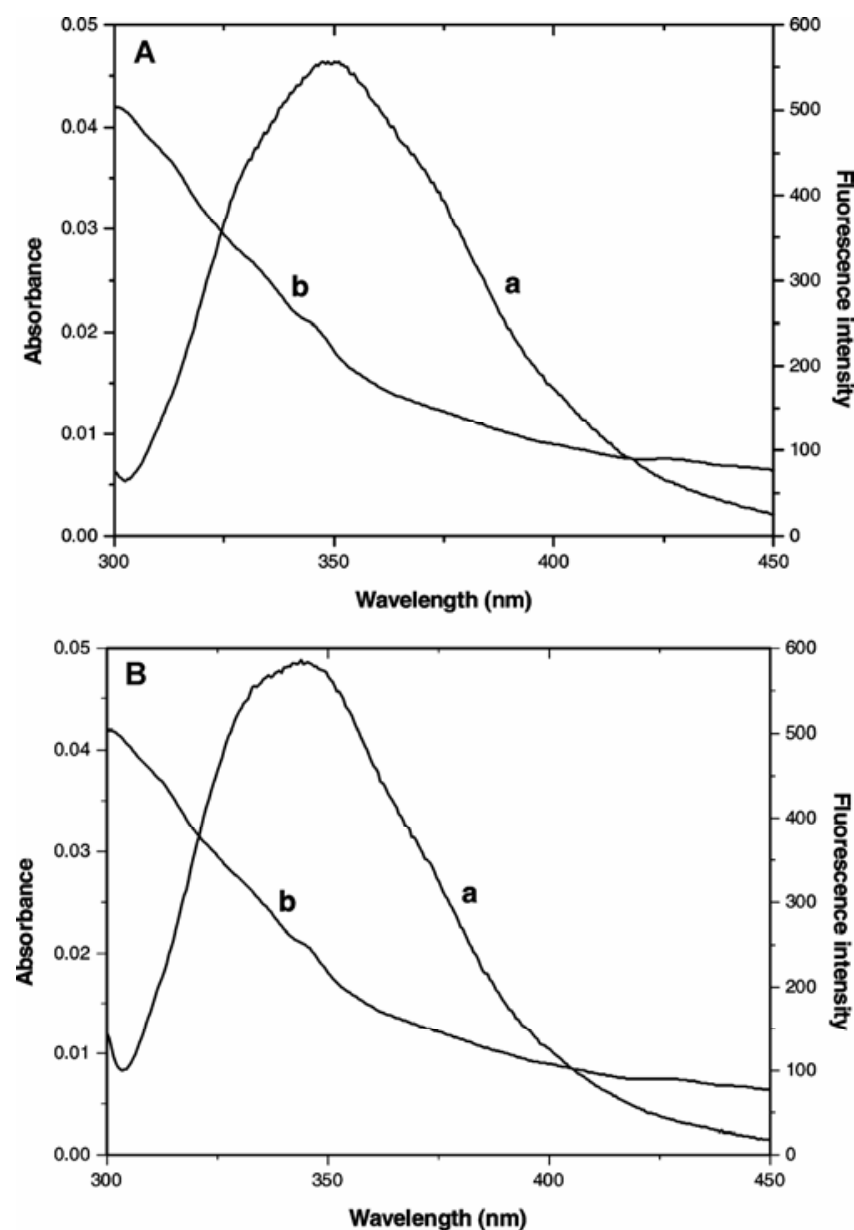

Figure 6. Overlapping between the fluorescence emission spectrum of $\alpha$-Chy (a) $(\lambda \mathrm{ex}=280 \mathrm{~nm})$ and UV absorption spectrum of CdTe QDs (b). (a) $\mathrm{pH}=9.05$, (b) $\mathrm{pH}=7.20 ; \quad[\alpha$-Chy $]=1.6 \times 10^{-6} \mathrm{M}, \quad[\mathrm{CdTe}]=3.6 \times$ $10^{-5} \mathrm{M}, \mathrm{T}=298 \mathrm{~K}$.
In the present case, it turns out that $k^{2}=2 / 3$, $N=1.366$, and $\Phi=0.118 .^{33}$ It was then calculated that $J=2.498 \times 10^{-15} \mathrm{~cm}^{3} \mathrm{~L} \mathrm{~mol}^{-1}, E=0.3051, r=$ $2.232 \mathrm{~nm}(\mathrm{pH}=9.05)$ and $E=0.4121, r=2.065 \mathrm{~nm}$ $(\mathrm{pH}=7 \cdot 20)$. As the distance of donor to acceptor for $\mathrm{CdTe}-\alpha$-Chy binding is less than $8 \mathrm{~nm}$, the energy transfer from $\alpha$-Chy to CdTe occurs with high probability. From figure 7 it can be seen that the fluorescence intensity of QDs in presence of $\alpha$-Chy is significantly higher than that of pure QDs and an isoemission point occurs at $460 \mathrm{~nm}$, which indicated that there are effective energy transfer between $\alpha$ Chy and QDs, and the complex compound has been formed between $\alpha$-Chy and QDs.
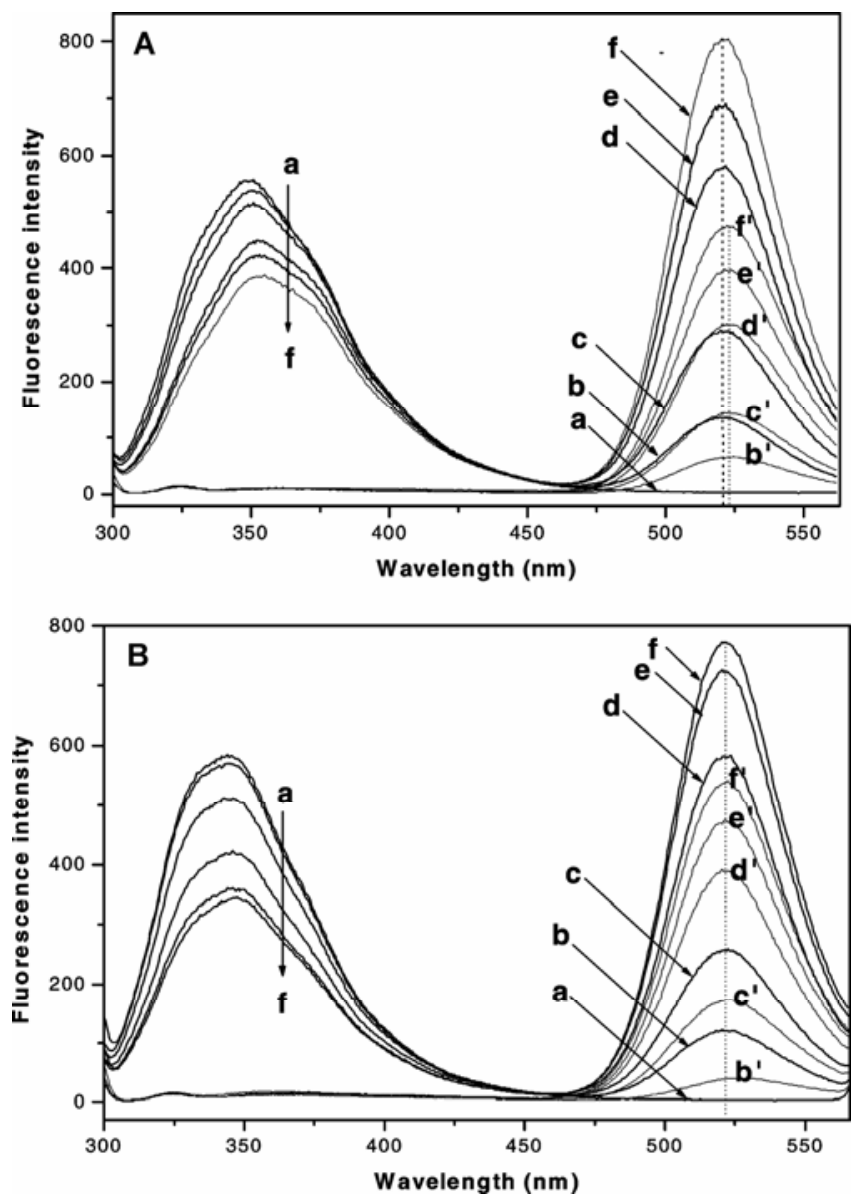

Figure 7. Energy transfer between $\alpha$-Chy and CdTe QDs. (A) $\mathrm{pH}=9.05$ (B) $\mathrm{pH}=7.20$; The concentration of $\alpha$-Chy from (a) to (f) was fixed as $1.6 \times 10^{-6} \mathrm{M}$, the concentrations of CdTe QDs were $0,6.00 \times 10^{-6}, 1.20 \times 10^{-5}$, $2.40 \times 10^{-5}, 3.00 \times 10^{-5}, 3.60 \times 10^{-5} \mathrm{M}$; the concentrations of CdTe QDs in the absence of $\alpha$-Chy from $\left(b^{\prime}\right)$ to $\left(\mathrm{f}^{\prime}\right)$ were $6.00 \times 10^{-6}, 1.20 \times 10^{-5}, 2.40 \times 10^{-5}, 3.00 \times$ $10^{-5}$, and $3.60 \times 10^{-5} \mathrm{M}$, respectively; $\mathrm{T}=298 \mathrm{~K}$. 

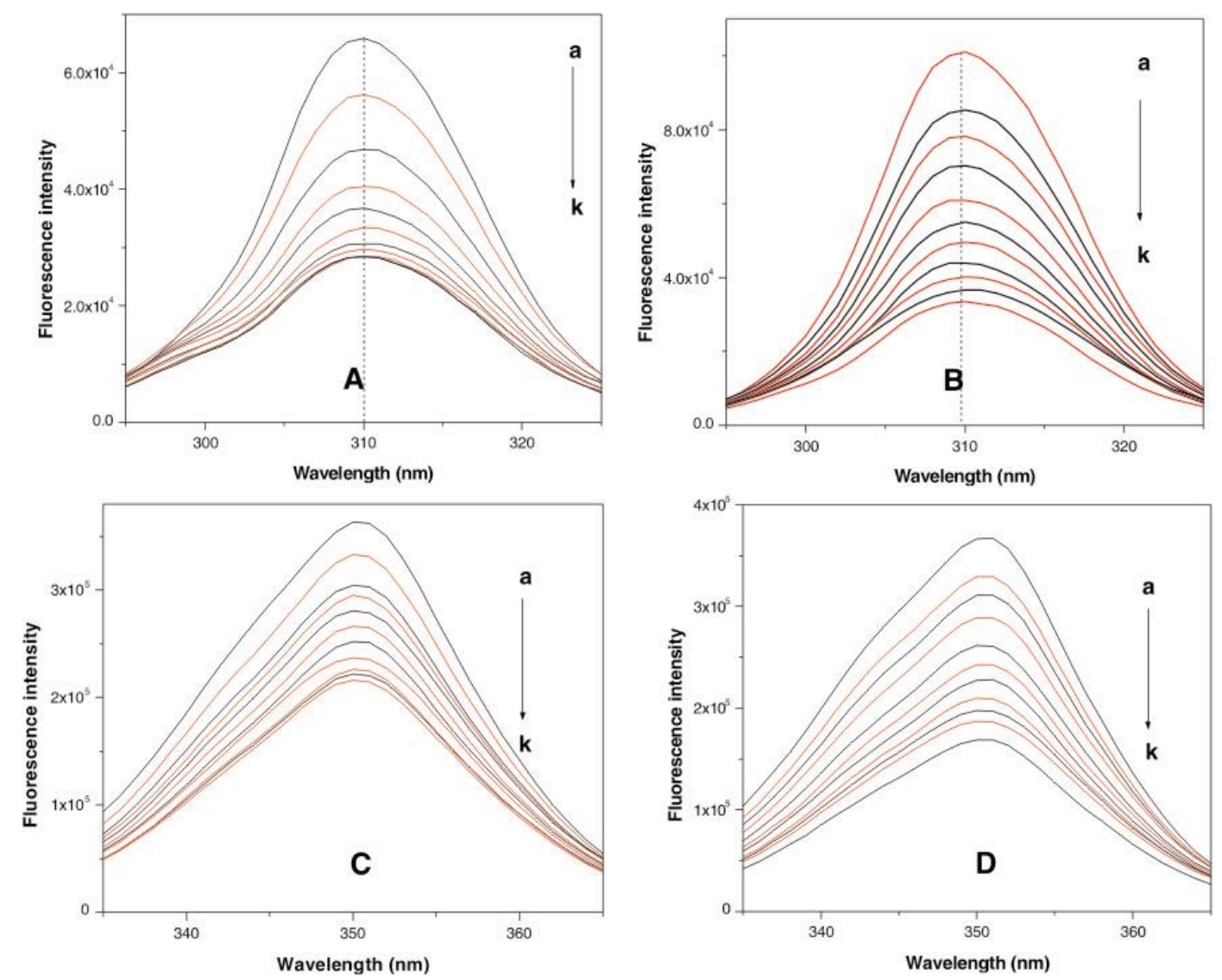

Figure 8. The synchronous fluorescence spectra of $\alpha$-Chy with varying the concentration of CdTe QDs. (A, B) $\Delta \lambda=15 \mathrm{~nm},(\mathbf{C}, \mathbf{D}) \Delta \lambda=60 \mathrm{~nm},(\mathrm{~A}, \mathrm{C}) \mathrm{pH}=9 \cdot 05,(\mathbf{B}, \mathbf{D}) \mathrm{pH}=7 \cdot 20$. The concentration of $\alpha$-Chy was fixed as $1.6 \times 10^{-6} \mathrm{M}$; the concentrations of CdTe QDs from (a) to (k) were $0,6.00 \times 10^{-6}, 1.20 \times 10^{-5}, 1.80 \times 10^{-5}, 2.40 \times 10^{-5}, 3.00 \times 10^{-5}, 3.60 \times 10^{-5}$, $4.20 \times 10^{-5}, 4.80 \times 10^{-5}, 5 \cdot 40 \times 10^{-5}$ and $6.00 \times 10^{-5} \mathrm{M}$, respectively.

Table 3. Stability of $\alpha$-chymotrypsin $\left(C=1.6 \times 10^{-6} \mathrm{M}\right)$ in different concentration of CdTe.

\begin{tabular}{|c|c|c|c|c|c|c|c|}
\hline \multirow[b]{2}{*}{$\mathrm{pH}$} & \multirow[b]{2}{*}{$\mathrm{C}(\mathrm{CdTe}) \times 10^{-5} \mathrm{M}$} & \multirow{2}{*}{$\begin{array}{l}\text { Enzyme activity } \\
\text { (ATEE U/mg) }\end{array}$} & $0 \cdot 5 \mathrm{~h}$ & $2 \cdot 5 \mathrm{~h}$ & $6 \cdot 5 \mathrm{~h}$ & $10 \cdot 5 \mathrm{~h}$ & $24 \mathrm{~h}$ \\
\hline & & & \multicolumn{5}{|c|}{ Relative enzyme activity (\%) } \\
\hline \multirow[t]{4}{*}{$9 \cdot 05$} & 0 & 4375 & 100 & $97 \cdot 14$ & $94 \cdot 29$ & $95 \cdot 13$ & $91 \cdot 43$ \\
\hline & $1 \cdot 2$ & & 91.43 & $94 \cdot 29$ & 91.43 & $85 \cdot 71$ & $77 \cdot 14$ \\
\hline & $6 \cdot 0$ & & $89 \cdot 25$ & $85 \cdot 71$ & $80 \cdot 00$ & $79 \cdot 43$ & $74 \cdot 29$ \\
\hline & $12 \cdot 0$ & & $77 \cdot 14$ & $77 \cdot 14$ & $74 \cdot 29$ & $77 \cdot 14$ & 71.43 \\
\hline \multirow[t]{4}{*}{$7 \cdot 20$} & 0 & 4000 & 100 & $98 \cdot 13$ & $96 \cdot 88$ & $93 \cdot 75$ & $93 \cdot 13$ \\
\hline & $1 \cdot 2$ & & $90 \cdot 63$ & $93 \cdot 75$ & $87 \cdot 50$ & $90 \cdot 63$ & $87 \cdot 50$ \\
\hline & $6 \cdot 0$ & & $87 \cdot 50$ & $84 \cdot 38$ & $81 \cdot 25$ & $78 \cdot 13$ & $77 \cdot 50$ \\
\hline & $12 \cdot 0$ & & $75 \cdot 00$ & $78 \cdot 13$ & $79 \cdot 38$ & $75 \cdot 00$ & $68 \cdot 75$ \\
\hline
\end{tabular}

\subsection{Conformational investigations}

Synchronous fluorescence spectroscopy (SFS) is a fluorescence spectrum obtained by a synchronous motion of an excitation and emission monochromator at the same rate, but with a constant difference of wavelength $\Delta \lambda$. SFS can provide simplified spectrum with sharp emission peaks. As $\Delta \lambda$ between excitation wavelength and emission wavelength is $15 \mathrm{~nm}$, synchronous fluorescence offers characteristics of tyrosine residues, when $\Delta \lambda$ is $60 \mathrm{~nm}$, it provides the characteristic information of tryptophan residues. 
Synchronous fluorescence spectra of $\alpha$-Chy upon addition of CdTe QDs gained at $\Delta \lambda=15$ and $60 \mathrm{~nm}$ are shown in figure 8 under two $\mathrm{pH}$ values.

As shown in figure 8, fluorescence intensity of both tryptophan and tyrosine decreases and a slightly red shift at maximum emission is observed on addition of $\mathrm{CdTe}$, which indicates that the conformation of protein is changed. It is likely that due to the hydrophobic amino acid structure surrounding tryptophan and tyrosine residues in $\alpha$-Chy tends to collapse slightly and thus tryptophan and tyrosine residues are more exposed to the aqueous phase.

$\mathrm{CD}$ is also a sensitive technique to monitor the conformational changes in proteins arising from interaction with a ligand. According to a quantitative
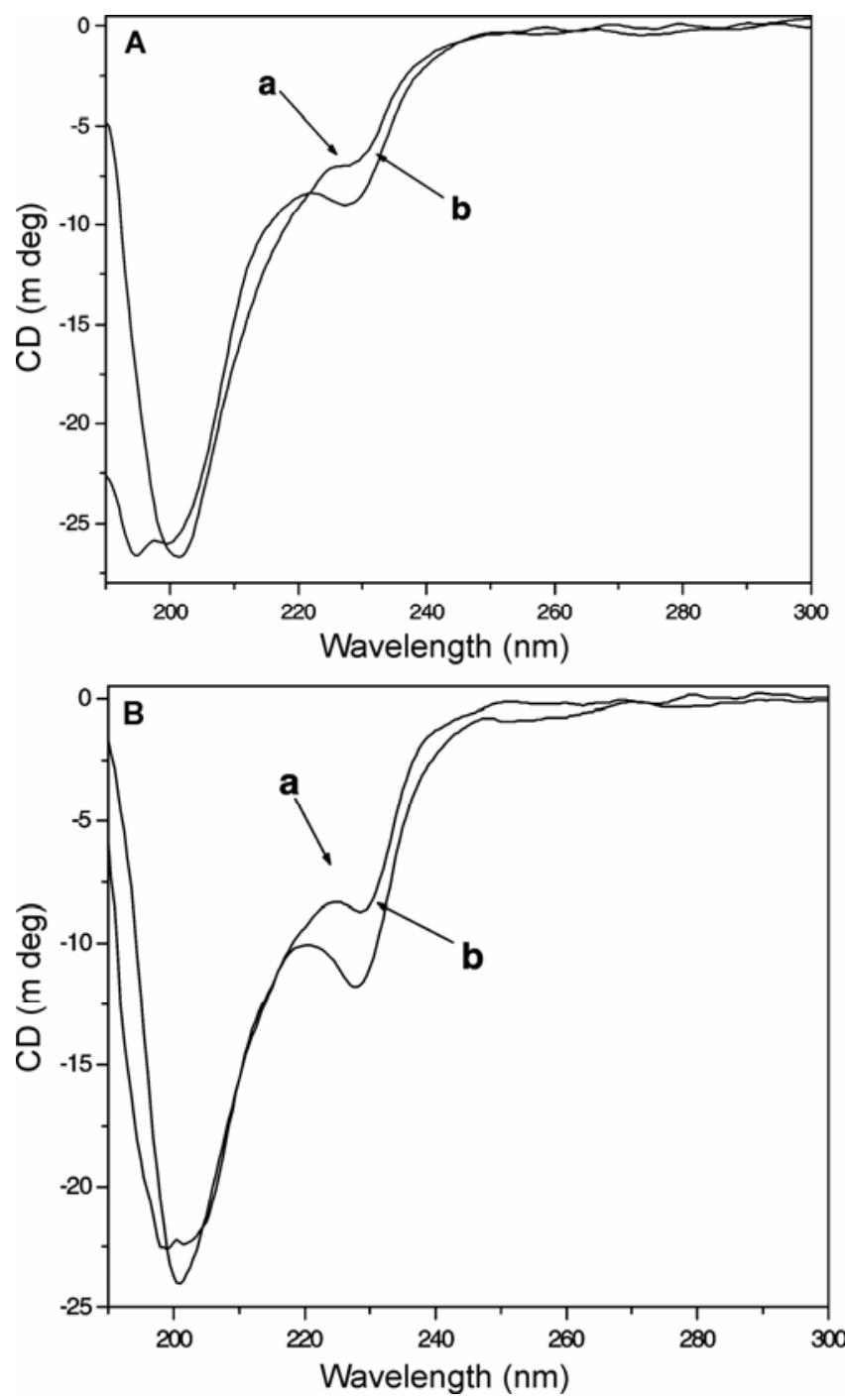

Figure 9. CD Spectra of the $\alpha$-Chy -CdTe System. (A) $\mathrm{pH}=9.05$ (B) $\mathrm{pH}=7.20$; (a) $1.6 \times 10^{-6} \mathrm{M} \alpha$-Chy, (b) $1.6 \times 10^{-6} \mathrm{M} \alpha$-Chy in the presence of $6.0 \times 10^{-5} \mathrm{M} \mathrm{CdTe}$ QDs. analysis by Fourier transform infrared spectroscopy, $\alpha$-Chy adopts a $50 \% \beta$-structure in $\mathrm{D}_{2} \mathrm{O} . \alpha$-Chy is a type of all- $\beta$ proteins characterized by a CD spectrum which resembles that of a random coil conformation. ${ }^{34}$ Figure 9 displays the CD spectra of $\alpha$-Chy with various amounts of CdTe QDs under two $\mathrm{pH}$ values. It is noticed from figure 9 that the secondary structure of $\alpha$-Chy is slightly different at two $\mathrm{pH}$ values. The $\mathrm{CD}$ spectrum of the native structure shows a global minimum around $205 \mathrm{~nm}$, which has been attributed to the $\beta$-strand conformation in $\beta$ barrel architecture observed in the crystal structure of $\alpha$-chymotrypsin (e.g. in 1ACB.pdb). Upon addition of CdTe QDs, the far-UV CD spectrum of the protein reveals a significant increase in signal intensities of $228 \mathrm{~nm}$ and decrease in the intensity of $203 \mathrm{~nm}$, which indicated the $\alpha$-helix and $\beta$-sheet structure content of $\alpha$-Chy has been changed and it may be the result of the formation of complex between the $\alpha$-Chy and CdTe.

\subsection{Assay of enzyme activities}

In order to investigate the activity and stability of $\alpha$ Chy in the absence and presence of CdTe QDs, activities of $\alpha$-Chy after storage in the two $\mathrm{pH}$ values ( $\mathrm{pH} 9.05, \mathrm{pH} 7.20)$ at $298 \mathrm{~K}$ were determined by measuring the absorbance at $237 \mathrm{~nm}$. The measurements were performed at intervals of a few hours during a period of $24 \mathrm{~h}$. As shown in table 3, when $\alpha$-Chy in the absence of CdTe QDs show high activity. The activity of $\alpha$-Chy still had a residual activity of $91.43 \%$ at $\mathrm{pH} 9.05$ and $93.13 \%$ at $\mathrm{pH} 7.20$. It should be noted that the high catalytic activities of the enzymes under two $\mathrm{pH}$ values can be explained not only by the similar overall structures of the proteins, but also by very little changes at the substrate binding site. It can be seen that the activity of $\alpha$-Chy in the presence of a small quantity of CdTe had no significant loss. The results showed that $\alpha$-Chy could maintain its high activity and stability in different $\mathrm{pH}$ values for $24 \mathrm{~h}$.

\section{Conclusions}

The interactions between CdTe QDs and $\alpha$-Chy were investigated by fluorescence quenching method. Results showed that CdTe quenched the fluorescence of $\alpha$-Chy through static quenching mechanism. Hydrogen bonds or van der Waals force is involved in the binding process when $\mathrm{pH}$ is 9.05 , 
while the hydrophobic and electrostatic interactions are involved in the binding process when $\mathrm{pH}$ is 7.20. The distance $(r)$ between donor and acceptor is obtained from Förster non-radioactive resonance energy transfer theory. Synchronous spectra and CD spectra reveal that CdTe QDs can change the conformation of $\alpha$-Chy. Furthermore, $\alpha$-Chy could maintain its high activity and stability under different $\mathrm{pH}$ values for $24 \mathrm{~h}$ in the presence of CdTe QDs.

\section{References}

1. Michalet X, Pinaud F F, Bentolila L A, Tsay J M, Doose S, Li J J, Sundaresan G, Wu A M, Gambhir S S and Weiss S 2005 Science 307538

2. Bruchez M, Moronne M, Gin Weiss P S and Alivisatos A P 1998 Science $\mathbf{2 8 1} 2013$

3. Chan W C W and Nie S M 1998 Science 2812016

4. Schreder B, Schmidt T and Ptatschek V 2000 J. Phys. Chem. B104 1677

5. Wang S, Mamedova N, Kotov N A, Chen W and Studer J 2002 Nano Lett. 2817

6. Chen, F and Gerion D 2004 Nano Lett. 41827

7. Chen, Q D, Ma Q, Wan Y, Su X G, Lin Z B and Jin Q H 2005 Luminescence 20251

8. Goldman E R, Balighian E D, Mattoussi H, Kuno M K, Mauro J M, Tran P T and Anderson G P $2002 \mathrm{~J}$. Am. Chem. Soc. 1246378

9. Parak W J, Gerion D, Zanchet D, Woerz A S, Pellegrino T, Micheel C, Williams S C, Seitz M, Bruehl R E, Bryant Z, Bustamante C, Bertozzi C R and Alivisatos A P 2002 Chem. Mater. 142113

10. Cao Y C, Huang Z L, Liu T C, Wang H Q, Zhu X X, Wang Z, Zhao Y D, Liu M X and Luo Q M Anal. Biochem. 2006351193

11. Schmid A, Dordick J S, Hauer B, Kiener A, Wubbolts M and Witholt B 2001 Nature 409258

12. Katz E and Willner I 2004 Angew. Chem. Int. Ed. 43 6042
13. Drauz K and Waldmann H 1995 Enzyme catalysis in organic synthesis (Weinheim: VCH) 1st edn

14. Fersht A 1985 Enzyme structure and mechanism (New York: W. H. Freeman) 2nd edn

15. Stryer L 1995 Biochemistry (New York: W.H. Freeman and Company) 4th edn

16. Barbaric S and Luisi P L $1981 \mathrm{~J}$. Am. Chem. Soc. 103 4239

17. Nicoletta S, Francesco A, Maria C, Franca D-A, Raimondo G, Gianfranco S 1999 J. Mol. Catal. B6 99

18. Schellenberger V, Braune K, Hofmann H-J and Jakubke H-D 1991 Eur. J. Biochem. 199623

19. Hao E, Zhang H, Yang B and Ren H $2001 \mathrm{~J}$. Colloid Interface Sci., 238285

20. Zhang H, Zhou Z, Yang B and Gao M 2003 J. Phys. Chem. B107 8

21. Simon L M, Kotormán M, Garab G and Laczko I 2001 Biochem. Biophys. Res. Commun. 2801367

22. Yu W W, Qu L H, Guo W Z and Peng X G 2003 Chem. Mater. 152854

23. Sulkowska A 2002 J. Mol. Struct. 614227

24. Cho Y, Wei G, Wakins S, Sam-Pin L, Tae-Rak K, John W B and Carl A B 1994 Protein Eng. 7263

25. Drevensek P, Turel I and Ulrih N 2003 J. Inorg. Biochem. 96407

26. Xie M X, Long M, Liu Y, Qin C and Wang Y 2006 Biochim. Biophys. Acta 17601184

27. Ware W R 1962 J. Phys. Chem. 66455

28. Lehrer S S 1971 Biochem. 103254

29. Mahtab R, Rogers J P, Singleton C P and Murphy C J 1996 J. Am. Chem. Soc. 1187028

30. Mohanned H R, Toru M and Tomoko Q 1993 Biochem. Pharm. 461721

31. Shen X C, Liu X Y, Ye L P, Liang H and Wang Z Y 2007 J. Colloid Interface Sci. 311400

32. Aaron R C, Medintz L L and Matthew M $2004 \mathrm{~J}$. Am. Chem. Soc. 126301

33. Cui F L, Fan J, Li J P and Hu Z D 2004 Bioorg. Med. Chem. 12151

34. Manavalan P and Johnson C 1983 Nature 305 831 